\title{
KEMITRAAN BIDAN DESA DAN DUKUN BAYI \\ DALAM MENINGKATKAN DERAJAT KESEHATAN IBU DAN ANAK DI KABUPATEN KONAWE SELATAN
}

Dewi Anggraini ${ }^{1}$, M. Najib Husain ${ }^{2}$, La Ode Monto Bauto ${ }^{3}$

${ }^{123}$ Fakultas Ilmu Sosial dan Ilmu Politik Universitas Halu Oleo

Jl. HEA Mokodompit No.1 Kampus Bumi Tridharma Anduonohu, Kendari 93232

\section{RINGKASAN}

Tujuan dari penelitian ini adalah Untuk mengetahui kemitraan bidan desa dan dukun bayi dalam meningkatkan derajat kesehatan ibu dan anak di Kabupaten Konawe Selatan. Penelitian ini merupakan penelitian kualitatif. Penelitian dilakukan di Kabupaten Konawe Selatan, dengan mengambil sampel pada pada lokasi atau wilayah yang memiliki angka kematian ibu melahirkan dan angka kematian bayi/balita cukup tinggi di Kabupaten Konawe Selatan. Informan dalam penelitian ini adalah 5 Bidan Desa dan 5 Dukun Bayi. Teknik penentuan informan dilakukan secara Purposive Sampling. Teknik pengumpulan data di lapangan pada penelitian ini menggunakan Teknik observasi, wawancara mendalam dan dokumentasi. Hasil penelitian Kemitraan bidan dengan dukun bayi adalah suatu bentuk kerjasama bidan dengan dukun bayi yang saling menguntungkan dengan prinsip keterbukaaan, kesetaraan, dan kepercayaan dalam upaya untuk menyelamatkan ibu dan bayi, dengan menempatkan bidan sebagai penolong persalinan dan mengalihfungsikan dukun dari penolong persalinan menjadi mitra dalam merawat ibu dan bayi pada masa nifas, dengan berdasarkan kesepakatan yang telah dibuat antara bidan dengan dukun, serta melibatkan seluruh unsur atau elemen masyarakat yang ada. Bidan desa dan Dukun bayi memiliki peran dan kepentingan yang berbeda tetapi diikat oleh satu tujuan yang sama yaitu keberadaan mereka dapat meningkatkan kesehatan ibu dan anak. Kesimpulan dalam penelitian ini bahwa Kemitraan antara bidan desa dan dukun bayi di Kabupaten Konawe Selatan terjalin dengan baik, melalui kemitraan bidan desa dan dukun bayi telah terjadi pengelolaan identitas yag diikuti dengan pembagian peran anatara bidan desa dan dukun bayi dalam proses sebelum persalinan dan setelah persalinan. Kemitraan yang terjadi juga tidak menghilangkan eksistensi dukun bayi di Kabupaten Konawe Selatan namun menjadikan dukun bayi sebagai mitra bidan desa dalam membantu meningkatkan derajat kesehatan ibu dan anak di Kab. Konawe Selatan. Saran, dalam proses alih peran dan pembagian tugas antara bidan dengan dukun perlu disepakati mekanisme kemitraan yang dijalin antara mereka. Meskipun mekanisme sangat beragam tergantung keadaan, tetapi ada beberapa hal penting yang harus disepakati (dituangkan secara tertulis dalam nota kesepakatan antara bidan - dukun) yaitu mekanisme rujukan informasi ibu hamil, mekanisme rujukan kasus persalinan, mekanisme pembagian biaya persalinan dan jadwal pertemuan rutin bidan dengan dukun.

Kata kunci: kemitraan; bidan desa dan dukun bayi; derajat kesehatan 


\section{A. Latar Belakang \\ 1. (Analisis Situasi)}

Provinsi Sulawesi Tenggara, kasus kematian ibu pada tahun 2011-2015 berdasarkan data yang dilaporkan petugas Puskesmas mengalami fluktuasi yaitu pada tahun 2011 dilaporkan sebanyak 97 kasus, turun menjadi 84 kasus pada tahun 2012 dan turun lagi menjadi 79 kasus pada tahun 2013, tahun2014 dilaporkan ada 65 kasus dan pada tahun 2015 meningkat menjadi 67 kasus kematian. Sedangkan kasus kematian bayi/balita untuk tingkat Provinsi Sulawesi Tenggara tahun 2015 sebesar 66 kasus kematian bayi dan 233 kasus kematian balita (Dinkes Sultra, 2016:47).

Kabupaten Konawe Selatan adalah salah satu daerah yang cukup tinggi kematian ibu, kematian bayi dan kematian balita. Pada tahun 2015, terdapat 8 kasus kematian ibu, 19 kasus kematian balita dan 2 kasus kematian bayi. Selain itu, cakupan pelayanan kesehatan oleh tenaga kesehatan juga masih rendah yaitu $82,70 \%$ atau belum mencapai target nasional yaitu sebesar 90\% (Dinkes Sultra, 2016:54).

Tingginya kasus-kasus kematian pada ibu dan bayi/balita serta rendahnya pelayanan kesehatan oleh tenaga kesehatan disebabkan oleh berbagai faktor yaitu masalah ekonomi, rendahnya kunjungan ke tenaga kesehatan selama hamil, keterlambatan merujuk, terlambat sampai di fasilitas pelayanan kesehatan atau terlambat mendapat pertolongan yang dapat mengakibatkan kematian. Faktor lain yang juga sangat berpengaruh yaitu budaya. Di beberapa wilayah terutama pedesaan dan pedalaman, mayoritas masyarakatnya masih mempercayakan sepenuhnya pelayanan kesehatan kepada tenaga dukun maupun dukun bayi. Hal tersebut perlu mendapat perhatian pemerintah secara serius. Upaya-upaya yang dilakukan pemerintah yaitu melalui perbaikan dan penyediaan sarana dan infrastruktur kesehatan, peningkatan kualitas sumber daya manusia tenaga kesehatan khususnya bidan desa, pemberdayaan masyarakat melalui Pembinaan Kesejahteraan Keluarga (PKK) dan Kader Posyandu serta membangun kemitraan antara bidan dan dukun bayi.

Kemitraan bidan dengan dukun bayi adalah suatu bentuk kerjasama bidan dengan dukun bayi yang saling menguntungkan dengan prinsip keterbukaaan, kesetaraan, dan kepercayaan dalam upaya untuk menyelamatkan ibu dan bayi, dengan menempatkan bidan sebagai penolong persalinan dan mengalihfungsikan dukun dari penolong persalinan menjadi mitra dalam merawat ibu dan bayi pada masa nifas, dengan berdasarkan kesepakatan yang telah dibuat antara bidan dengan dukun, serta melibatkan seluruh unsur atau elemen masyarakat yang ada (Depkes RI, 2008:5)

Peranan dukun bayi di masyarakat dalam menolong seorang ibu selama masa kehamilan, persalinan dan sesudah persalinan berkaitan sangat erat dengan budaya dan kebiasaan setempat. Dukun bayi kebanyakan merupakan orang yang cukup dikenal di desa, dihormati, dianggap sebagai orang tua yang dapat dipercaya, dan sudah berpengalaman. Selain melakukan perawatan kehamilan, menolong persalinan, serta merawat ibu dan bayinya sesudah persalinan, dukun bayi umumnya dipercaya dapat memberikan kekuatan spiritual melalui doa-doa, mantra, dan ritual-ritual adat yang dilakukannya, sehingga memberikan rasa nyaman dan aman pada ibu yang akan melahirkan. 


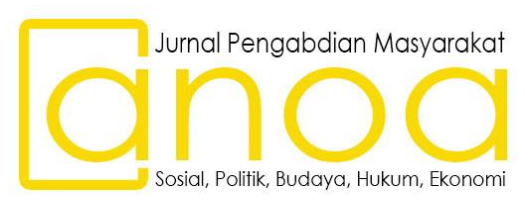

Vol. 1, No. 2, Hal. 84-91, Mei 2020

Fakta yang ada di lapangan, jumlah dukun bayi jauh lebih banyak dari jumlah bidan. Hal ini berbanding terbalik dengan keberadaan bidan yang relatif terbatas, khususnya di desa-desa dan daerah terpencil. Meskipun secara teknis bidan memiliki keahlian yang diakui dalam membantu persalinan, pengalaman dan usia yang umumnya masih muda (terutama bagi yang ditempatkan di daerah terpencil) seringkali menjadi hambatan dalam meraih kepercayaan masyarakat.

Berdasarkan fakta tersebut serta kebijakan pemerintah bahwa setiap persalinan ibu harus ditangani oleh tenaga kesehatan, maka upaya membangun kemitraan bidan dan dukun bayi menjadi sangat perlu dilakukan. Dukun bayi bersedia mengalihkan peranannya sebagai penolong persalinan kepada bidan, tetapi tetap berperan dalam merawat ibu selama masa kehamilan, mendampingi saat persalinan (dengan melakukan ritual adat atau keagamaan untuk membuat ibu merasa tenang dan aman), dan merawat ibu dan bayi setelah persalinan (masa nifas).

Sehingga Bidan dan Dukun Bayi memiliki peran penting dan saling melengkapi dalam pelaksanaan kemitraan. Peran-peran tersebut terbagi dalam beberapa fase yang dimulai dari periode kehamilan, periode persalinan, dan periode nifas. Adapun pembagian peran antara bidan dan dukun bayi dalam pelaksanaan kemitraan (Depkes RI, 2008:8)

Program kemitraan bidan dan dukun bayi telah lama berjalan sampai saat ini, tidak terkecuali di Konawe Selatan, Provinsi Sulawesi Tenggara. Saat ini tercatat 336 orang dukun bayi telah terlatih dan bermitra dengan bidan desa (Dinkes Konawe Selatan, 2015).Program kemitraan bidan dan dukun bayi telah tertuang dalam Peraturan Daerah Kabupaten Konawe Selatan Nomor 22 Tahun 2013 tentang Desa Mandara Mendidoha, pasal 46 ayat 2 berbunyi: tenaga kesehatan dan/atau bidan yang bertugas di desa wajib membangun hubungan yang baik dengan sando dan kelompok masyarakat. Namun, Program tersebut belum berjalan maksimal. Faktor sosial budaya dan ekonomi menjadi tantangan besar. Hal mendasar adalah belum terbangunnya kemitraan yang baik antara bidan desa dan dukun bayi, yaitu bagaimana seorang bidan mampu menempatkan dirinya pada suatu tatanan masyarakat, memahami identitas dirinya dan identitas dukun bayi yang menjadi mitranya di masyarakat. Berdasarkan latar belakang tersebut, maka rumusan masalah dalam penelitian ini yaitu: Bagaimana kemitraan bidan desa dan dukun bayi dalam meningkatkan derajat kesehatan ibu dan anak di Kabupaten Konawe Selatan?

\section{B. Metode Pelaksanaan}

Penelitian ini merupakan penelitian kualitatif. Penelitian kualitatif menurut Moleong (2007:6) adalah penelitian yang bermaksud untuk memahami fenomena tentang apa yang dialami oleh subyek peneltian misalnya perilaku, persepsi, motivasi, tindakan, dan lainnya, secara holistic, dan dengan cara deskripsi dalam bentuk katakata dan bahasa, pada suatu konteks khusus yang alamiah dengan memanfaatkan berbagai metode ilmiah.

Penelitian dilakukan di Kabupaten Konawe Selatan (Unit analisis kabupaten) dengan mengambil sampel pada pada lokasi atau wilayah yang memiliki angka kematian ibu melahirkan dan angka kematian bayi/balita cukup tinggi di Kabupaten 


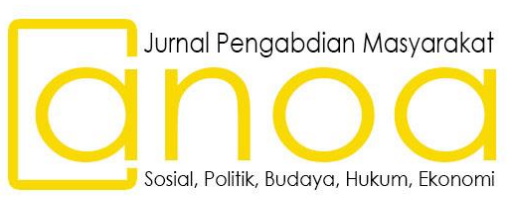

Vol. 1, No. 2, Hal. 84-91, Mei 2020

Konawe Selatan. Informan dalam penelitian ini adalah 5 Bidan Desa dan 5 Dukun Bayi. Teknik penentuan informan dilakukan secara Purposive Sampling.

Teknik pengumpulan data di lapangan pada penelitian ini menggunakan Teknik observasi, wawancara mendalam dan dokumentasi. Analisis data menurut Patton (Moleong, 2004:103) adalah proses mengatur urutan data mengorganisasikan ke dalam suatu pola, kategori dan satuan urutan dasar. Analisis data merupakan upaya mencari dan mensistematiskan catatan hasil observasi, wawancara juga dokumentasi yang dilakukan dalam proses penelitian, untuk meningkatkan pemahaman peneliti atas temuan-temuan permasalahan yang diteliti.

\section{Hasil Dan Pembahasan}

\section{Kemitraan Bidan Desa Dan Dukun Bayi}

Kemitraan bidan dengan dukun bayi adalah suatu bentuk kerjasama bidan dengan dukun bayi yang saling menguntungkan dengan prinsip keterbukaaan, kesetaraan, dan kepercayaan dalam upaya untuk menyelamatkan ibu dan bayi, dengan menempatkan bidan sebagai penolong persalinan dan mengalihfungsikan dukun dari penolong persalinan menjadi mitra dalam merawat ibu dan bayi pada masa nifas, dengan berdasarkan kesepakatan yang telah dibuat antara bidan dengan dukun, serta melibatkan seluruh unsur atau elemen masyarakat yang ada. Dalam membangun kemitraan ini terdapat faktor yang akan mempengaruhi komunikasi yang dilakukan oleh bidan desa dan dukun bayi di Kabupaten Konawe Selatan. Berdasarkan hasil penelitian, Identitas Bidan desa dan Dukun bayi dapat tergambar melalui cara mereka melakukan interaksi komunikasi dan strategistrategi yang mereka gunakan untuk mempertahankan hubugan komunikasi sehingga hubungan atau kemitraan yang mereka jalin dapat menghasilkan rasa saling menghormati dan saling percaya sehingga interaksi yang terjadi dapat berjalan lancar dan menyenangkan

Berdasarkan hasil penelitian, proses kemitraan tersebut dilakukan secara langsung oleh bidan desa melalui pertemuan-pertemuan yang dilakukan dengan dengan dukun bayi. Seperti yang diuangkapkan oleh salah satu informan penelitian bernama lina, salah seorang dukun bayi di Kecamatan Andoolo yang mengatakan bahwa

"Kalau kita disini biasanya itu diundang dengan bidan desa untuk datang pertemuan dibalai desa atau di puskesmas. Biasanya kita diundang itu 1 sampai 2 kali dalam satu tahun, tapi tidak semua juga dukun yang hadir, mungkin karena dorang tidak tahu jadi tidak datang. Saya sendiri sampai sekarang baru 5 kali ikut pertemuan dengan bidan desa". (Wawancara, 10 Agustus September 2019).

Berdasarkan hasil wawancara diatas, Petemuan antara bidan desa dana dukun bayi dilakukan setiap tahun. Dalam pertemuan tersebut dilakukan pelatihanpelatihan untuk penanganan ibu hamil dan bayi yang ada di Kabupaten Konawe Selatan. Pertemuan membahas masalah kesehatan seperti masalah ibu hamil, bagaimana persalinan, bagaimana keadaan ibu dan bayi setelah melahirkan, pertumbuhannya dan juga kadang membahas masalah kesehatan lainnya seperti 
macam-macam penyakit yang ada di masyarakat, bagaiman menjaga kebersihan lingkungan.

Bidan desa dan Dukun bayi memiliki identitas yang berbeda seperti etnik, wilayah, jenis kelamin, usia, pekerjaan, kelompok sosial, hobi maupun pengalaman. Identitas memiliki fungsi yang penting dalam proses komunikasi. Identitas yang dimiliki oleh komunikator dan komunikan akan mempengaruhi proses pengiriman dan penerimaan pesan. Identitas dalam penelitian ini, adalah identitas yang dibentuk dan dimiliki oleh bidan desa dalam membangun kemitraan dengan dukun bayi. Identitas yang dimiliki tersebut, kemudian akan ditunjukkan melalui penggunaan simbol-simbol komunikasi kepada dukun bayi untuk membentuk citra diri bidan desa di mata dukun bayi dan masyarakat Kab. Konawe Selatan. Pembentukan citra diri yang baik akan memberikan dampak positif terhadap penerimaan masyarakat pada bidan desa.

Identitas yang dibangun oleh bidan desa dalam membangun kemitraan dengan dukun bayi melalui komunikasi langsung kepada masyarakat untuk membangun kepercayaan bahwa bidan desa merupakan orang yang tepat untuk menolong proses persalinan ibu hamil. Identitas yang dibangun oleh bidan desa saat ini telah mampu membangun kepecayaan ditengah masyarakat, hal tersebut telihat dari tidak adanya lagi kasus pesalianan yang dilakukan oleh dukun bayi di wilayah kerja mereka.

\section{Identifikasi Hubungan dan Budaya}

Identifikasi dan perasaan diterimanya seseorang sebagai bagian dari sebuah kelompok yang berbagi tanda dan makna serta norma atau aturan yang membentuk perilaku tertentu. Bidan desa dan Dukun bayi memiliki peran dan kepentingan yang berbeda tetapi diikat oleh satu tujuan yang sama yaitu keberadaan mereka dapat meningkatkan kesehatan ibu dan anak. Bidan desa sebagai individu yang ditempatkan oleh pemerintah di suatu daerah atau wilayah tertentu harus mampu beradaptasi dengan budaya masyarakat setempat sehingga mampu diterima menjadi bagian dari kelompok masyarakat tersebut begitupun juga sebaliknya dengan Dukun bayi diharapkan mampu menerima kehadiran Bidan desa sebagai mitra atau parnert kerja dalam menyukseskan program pemerintah. Tujuan tersebut dapat tercapai jika Bidan desa dan Dukun bayi melakukan interaksi komunikasi dan memiliki kesamaan makna.

Hasil wawancara dengan informan penelitian yag berprofesi sebagai bidan desa di Kelurahan Ranometo, mengatakan bahwa:

"terkait penggunaan bahasa daerah, wilayah andoolo mayoritas suku tolaki dan dukunnya juga suku tolaki, sementara saya sebagai bidan desa suku bugis, dukun bayi rata-rata tidak terlalu fasih menggunakan bahasa indonesia, untuk mengatasinya saya meminta bantuan kader posyandu atau keluarga dukun untuk menjelaskan dalam bahasa indonesia".

Kemitraan yang dibangun melalui proses komunikasi menjadi lebih efektif ketika terjadi persamaan makna antar pengirim pesan (komunikator) dan penerima pesan (Komunikan). Penggunaan bahasa daerah yang sama antara bidan desa 


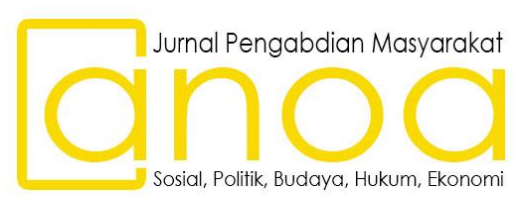

Vol. 1, No. 2, Hal. 84-91, Mei 2020

dan dukun bayi relational culture diantara mereka, sehingga kemitraan antara bidan desa dan dukun bayi menjadi semakin baik dalam meningkatkan derajat kesehatan ibu da anak di Kabupaten Konawe Selatan.

Selanjutnya, identitas dukun bayi merupakan identitas yang dimiliki oleh seseorang karena keahliannya dalam membantu proses persalinan karena kepercayaan masyarakat bahwa dukun bayi dapat menolong proses persalinan seseorang, identitas tersebut tidak didapat dari proses belajar formal namun diberikan oleh masyarakat. Kepercayaan tersebut terbentuk secara turun-temurun dalam masyarakat, sehingga dukun bayi merupakan orang yang dituakan dalam masyarakat.

Berdasarkan hasil penelitian, adanya 2 identitas tersebut menyebabkan terjadinya kesulitan dalam meningkatkan derajat kesehatan ibu dan anak di Kabupaten Konawe Selatan, karena masih banyaknya kepercayaan masyarakat terkait ibu hamil dan proses melahirkan bayi yag berkembag di tengah masyarakat. seperti hasil wawancara dengan salah satu bidan desa Annisa, Am.Keb yang mengatakan bahwa;

"kesulitan terkait budaya atau tradisi masyarakat setempat, pada saat ibu hamil banyak pantangan atau pamali yang harus diikuti, yang menurut ilmu kesehatan itu adalah pandangan yang keliru, misalnya soal makanan, pada masa setelah melahirkan tidak boleh makan terong karena dapat menyebabkan si ibu dan bayi gatal-gatal, padahal terong mengandung vitamin A dan C yang baik bagi kesehatan".

Berdasarkan hasil wawancara tersebut, terdapat kesulitan dalam meningkatkan derajat kesehatan ibu dan anak di Kab. Koawe Selatan karena masih adanya kepercayaan masyarakat terkait ibu dan anak yang bertentangan dengan fakta medis. oleh karena itu dibutuhkan kemitraan anatar bidan desa dan dukun bayi untuk merubah pola pikir dan kebiasaan yag berlangsung ditengah masyarakat yang tidak sesuai dengan fakta medis untuk meningktkan derajat kesehatan ibu dan anak di Kab. Koawe Selatan.

\section{Cara Pandang Dalam Permasalahan Ibu Hamil}

Bidan desa dan dukun bayi di Kabupaten Konawe Selatan tetap dibutuhkan oleh masyarakat dalam membantu ibu hamil. namun peran yag dimiliki oleh dukun bayi sudah dikurangi dalam hal memberikan pertolongan pada proses melahirkan. Dukun bayi hanya dapat mendampingi bidan desa tanpa terlibat langsung pada proses persalinan ibu dan bayi. Kedua identitas tersebut telah menyadari dan mengetahui peran dan fungsi masing-masing dalam meningkatkan derajat kesehatan ibu dan anak di Kabupaten Konawe Selatan.

Hasil wawacara dengan informan penelitian, Marina 53 tahun yang merupakan dukun bayi di desa Konda mengatakan bahwa ;

"saya dan bidan desa bersama-sama membantu proses kelahiran, semua ibu hamil yang akan melahirkan harus ke polindes tidak boleh lagi dilakukan di rumah masing-masing. kami dukun membantu mengantar ibu hamil sampai ke polindes. setelah ibu melahirkan, kami dukun membantu perawatan untuk ibunya, seperti mandi air panas, pijat, minum ramuan dan 
kadang juga bantu memandikan bayinya. bidan tetap melakukan kontrol kepada ibu yang sudah melahirkan".

Berdasarkan hasil penelitian, dukun bayi tidak lagi memiliki peran dalam proses persalinan bayi, karena harus dilakukan oleh bidan desa. mereka berperan setelah proses persalinan seperti memandikan ibu dan bayi, dan atau memberikan ramuan jamu yag dibutuhkan oleh ibu bayi. Selain itu, dukun bayi juga berperan dalam memberikan informasi kepada bidan desa terkait kasus kehamilan yang ada disekitarnya yang belum mendapat perhatian dari bidan desa. Kemitraan antara bidan desa dan dukun bayi telah mampu meningkatkan derajat kesehatan ibu dan anak di Kabupaten Konawe Selatan karena adanya pembagian peran yang dilakukan oleh bidan desa bersama dengan dukun bayi.

D. Kesimpulan Dan Saran
1. Kesimpulan
Kemitraan antara bidan desa dan dukun bayi di Kabupaten Konawe Selatan terjalin
dengan baik, melalui kemitraan bidan desa dan dukun bayi telah terjadi pengelolaan
identitas yag diikuti dengan pembagian peran anatara bidan desa dan dukun bayi
dalam proses sebelum persalinan dan setelah persalinan. Kemitraan yang terjadi
juga tidak menghilangkan eksistensi dukun bayi di Kabupaten Konawe Selatan namun
menjadikan dukun bayi sebagai mitra bidan desa dalam membantu meningkatkan
derajat kesehatan ibu dan anak di Kab. Konawe Selatan.

D. Kesimpulan Dan Saran
1. Kesimpulan
Kemitraan antara bidan desa dan dukun bayi di Kabupaten Konawe Selatan terjalin
dengan baik, melalui kemitraan bidan desa dan dukun bayi telah terjadi pengelolaan
identitas yag diikuti dengan pembagian peran anatara bidan desa dan dukun bayi
dalam proses sebelum persalinan dan setelah persalinan. Kemitraan yang terjadi
juga tidak menghilangkan eksistensi dukun bayi di Kabupaten Konawe Selatan namun
menjadikan dukun bayi sebagai mitra bidan desa dalam membantu meningkatkan
derajat kesehatan ibu dan anak di Kab. Konawe Selatan.

Kesimpulan Dan Saran
Kesimpulan
Kemitraan antara bidan desa dan dukun bayi di Kabupaten Konawe Selatan terjalin
dengan baik, melalui kemitraan bidan desa dan dukun bayi telah terjadi pengelolaan
identitas yag diikuti dengan pembagian peran anatara bidan desa dan dukun bayi
dalam proses sebelum persalinan dan setelah persalinan. Kemitraan yang terjadi
juga tidak menghilangkan eksistensi dukun bayi di Kabupaten Konawe Selatan namun
menjadikan dukun bayi sebagai mitra bidan desa dalam membantu meningkatkan
derajat kesehatan ibu dan anak di Kab. Konawe Selatan.

Kesimpulan Dan Saran
Kesimpulan
Kemitraan antara bidan desa dan dukun bayi di Kabupaten Konawe Selatan terjalin
dengan baik, melalui kemitraan bidan desa dan dukun bayi telah terjadi pengelolaan
identitas yag diikuti dengan pembagian peran anatara bidan desa dan dukun bayi
dalam proses sebelum persalinan dan setelah persalinan. Kemitraan yang terjadi
juga tidak menghilangkan eksistensi dukun bayi di Kabupaten Konawe Selatan namun
menjadikan dukun bayi sebagai mitra bidan desa dalam membantu meningkatkan
derajat kesehatan ibu dan anak di Kab. Konawe Selatan.

Kesimpulan Dan Saran
Kesimpulan
Kemitraan antara bidan desa dan dukun bayi di Kabupaten Konawe Selatan terjalin
dengan baik, melalui kemitraan bidan desa dan dukun bayi telah terjadi pengelolaan
identitas yag diikuti dengan pembagian peran anatara bidan desa dan dukun bayi
dalam proses sebelum persalinan dan setelah persalinan. Kemitraan yang terjadi
juga tidak menghilangkan eksistensi dukun bayi di Kabupaten Konawe Selatan namun
menjadikan dukun bayi sebagai mitra bidan desa dalam membantu meningkatkan
derajat kesehatan ibu dan anak di Kab. Konawe Selatan.

Kesimpulan Dan Saran
Kesimpulan
Kemitraan antara bidan desa dan dukun bayi di Kabupaten Konawe Selatan terjalin
dengan baik, melalui kemitraan bidan desa dan dukun bayi telah terjadi pengelolaan
identitas yag diikuti dengan pembagian peran anatara bidan desa dan dukun bayi
dalam proses sebelum persalinan dan setelah persalinan. Kemitraan yang terjadi
juga tidak menghilangkan eksistensi dukun bayi di Kabupaten Konawe Selatan namun
menjadikan dukun bayi sebagai mitra bidan desa dalam membantu meningkatkan
derajat kesehatan ibu dan anak di Kab. Konawe Selatan.

Kesimpulan Dan Saran
Kesimpulan
Kemitraan antara bidan desa dan dukun bayi di Kabupaten Konawe Selatan terjalin
dengan baik, melalui kemitraan bidan desa dan dukun bayi telah terjadi pengelolaan
identitas yag diikuti dengan pembagian peran anatara bidan desa dan dukun bayi
dalam proses sebelum persalinan dan setelah persalinan. Kemitraan yang terjadi
juga tidak menghilangkan eksistensi dukun bayi di Kabupaten Konawe Selatan namun
menjadikan dukun bayi sebagai mitra bidan desa dalam membantu meningkatkan
derajat kesehatan ibu dan anak di Kab. Konawe Selatan.

Kesimpulan Dan Saran
Kesimpulan
Kemitraan antara bidan desa dan dukun bayi di Kabupaten Konawe Selatan terjalin
dengan baik, melalui kemitraan bidan desa dan dukun bayi telah terjadi pengelolaan
identitas yag diikuti dengan pembagian peran anatara bidan desa dan dukun bayi
dalam proses sebelum persalinan dan setelah persalinan. Kemitraan yang terjadi
juga tidak menghilangkan eksistensi dukun bayi di Kabupaten Konawe Selatan namun
menjadikan dukun bayi sebagai mitra bidan desa dalam membantu meningkatkan
derajat kesehatan ibu dan anak di Kab. Konawe Selatan.

Kesimpulan Dan Saran
Kesimpulan
Kemitraan antara bidan desa dan dukun bayi di Kabupaten Konawe Selatan terjalin
dengan baik, melalui kemitraan bidan desa dan dukun bayi telah terjadi pengelolaan
identitas yag diikuti dengan pembagian peran anatara bidan desa dan dukun bayi
dalam proses sebelum persalinan dan setelah persalinan. Kemitraan yang terjadi
juga tidak menghilangkan eksistensi dukun bayi di Kabupaten Konawe Selatan namun
menjadikan dukun bayi sebagai mitra bidan desa dalam membantu meningkatkan
derajat kesehatan ibu dan anak di Kab. Konawe Selatan.

\section{Saran}

1. Membangun kerjasama antara semua elemen masyarakat untuk ikut serta dalam kemitraan bidan desa dan dukun bayi di Kab. Konawe Selatan melalui kegiatan pemberdayaan masyarakat.

2. Dalam proses alih peran dan pembagian tugas antara bidan dengan dukun perlu disepakati mekanisme kemitraan yang dijalin antara mereka. Meskipun mekanisme sangat beragam tergantung keadaan, tetapi ada beberapa hal penting yang harus disepakati (dituangkan secara tertulis dalam nota kesepakatan antara bidan dukun) yaitu mekanisme rujukan informasi ibu hamil, mekanisme rujukan kasus persalinan, mekanisme pembagian biaya persalinan dan jadwal pertemuan rutin bidan dengan dukun. Memberikan pelatihan kepada dukun bayi dan masyarakat terkait pentingnya kesehatan ibu dan anak melalui proses persalina dengan bida desa.

\section{DAFTAR PUSTAKA}

Hart,R.H,dkk. 2008. Kesehatan Ibu dan Anak dengan Pemeliharaan Kesehatan Dasa. Tangerang: Binarupa Aksara.

Hidayat,Asri dan Mufdlilah. 2008. Konsep Kebidanan. Yogyakarta: Mitra Cendikia Press. 
Ibrahim, Abdul Syukur. 1994. Panduan Penulisan Etnografi Komunikasi. Surabaya: Usaha Nasional.

Kriyantono, Rachmat. 2010. Teknis Praktis Riset Komunikasi. Jakarta: Kencana.

Little John, Stephen W. 2008. Teori Komunikasi. Jakarta: Kencana.

Manuaba, Ida Bagus Gde. 1998. Ilmu Kebidanan, Penyakit Kandungan dan Keluarga Berencana untuk Pendidikan Bidan. Jakarta: EGC.

Margono. 1997. Metodologi Penelitian Pendidikan. Jakarta: Rineka Cipta.

Moleong, Lexy J. 2004. Metode Penelitian Kualitatif. Bandung: Remaja Rosdakarya 2007. Metode Penelitian Kualitatif. Bandung: Remaja Rosdakarya.

Mulyana,Deddy. 2000. IImu Komunikasi, Suatu Pengantar. Bandung: Remaja Rosdakarya.

Mulyana,Deddy dan Solatun. 2008. Metode Penelitian Komunikasi, Contoh-contoh Penelitian Kualitatif dengan Pendekatan Praktis. Bandung: Remaja Rosdakarya.

Myles. 2011. Buku Ajar Bidan. In D. Fraser \& M. Cooper (Eds.), Kebidanan (Revisi.). Jakarta:EGC.

Nazir, Mohammad. 1988. Metode Penelitian. Jakarta: Ghalia Indonesia.

Noor, Juliansyah. 2011. Metodologi Penelitian, Skripsi, Tesis, Disertasi, dan Karya IImiah, Edisi I. Jakarta: Kencana Prenada Media Group.

Purwoastuti,Th.Endang dan Elisabeth Siwi Wahyuni. 2015. Mutu Pelayanan Kesehatan dan Kebidanan. Yogyakarta: Pustaka Baru. 